\title{
The principle of no significant harm in international water law
}

\author{
Susanne Schmeier ${ }^{1}$ Joyeeta Gupta ${ }^{1,2}$
}

Accepted: 21 October 2020 / Published online: 4 November 2020

(c) Springer Nature B.V. 2020

Human impacts on freshwater systems and related ecosystems are ever-growing as demands for water, food and energy increase. The development of large-scale irrigation systems in response to food insecurity can affect the availability of water for other uses and users. The use of fertilizers or pesticides in agriculture can negatively impact on the quality of a watercourse and affect other uses in the same basin. The construction of dams for hydropower generation in response to energy security challenges can disturb the flow of a river, its sediment transport or the migration of fish species, negatively affecting those that depend on these resources and ecosystem services for a living in the same or other parts of a basin. The abstraction of groundwater from an aquifer in order to meet water supply and sanitation needs of the population can impact on the availability of water for irrigation in the same or in a different region. And the growing use of modern technologies in the context of globalization can also have impacts on the access and harm to water. Such developments increasingly threaten ecosystems, livelihoods and economic opportunities of people. The use of water resources by one actor can thus cause harm to others. Increasing pressure on water resources - coupled with the impacts of global climate change-is likely to lead to such harm ever more often and more intensively in the future.

At the level of shared watercourses - rivers, lakes and aquifers that transcend the boundaries of nation states - these challenges are of even greater complexity. The use of water resources by one state can harm other states in the basin, potentially leading to tensions or conflicts between them. Such conflicts-as examples from around the world showcan have negative effects way beyond water resources and their sustainable management, including negative repercussions on economic relations, the deterioration of political relations and increasing regional instability.

Aiming at mitigating such risks - for the environment and the services it provides to people, communities and countries as well as for cooperation and peace-the principle of no significant harm has developed in international environmental law more generally and

Joyeeta Gupta

j.gupta@uva.nl

Susanne Schmeier

s.schmeier@un-ihe.org

1 IHE-Delft Institute for Water Education, Delft, The Netherlands

2 Amsterdam Institute of Social Science Research, University of Amsterdam, Amsterdam, The Netherlands 
in the field of international water law specifically. It was included in the 1997 UN Convention on the Law of the Non-navigational Uses of International Watercourses, the 1992 UNECE Convention on the Protection and Use of Transboundary Watercourses and International Lakes as well as in numerous basin-specific agreements and is widely reflected in state practice over shared water resources. Other international legal and political frameworks - such as the 2010 Resolution on the Human Right to Water and Sanitation and the 2015 Paris Agreement, and the 2030 Agenda and its Sustainable Development Goals (SDGs) - support the idea behind the principle, but are more ambiguous regarding how it is to be operationalized.

Hence, a number of challenges remain: In many basins and at many occasions, significant harm has not been prevented-in spite of the principle's prominence in international customary and treaty law and its wide recognition also at the political level. Ever-growing demand for water-coupled with and driven by developments such as economic growth, urbanization, population growth and climate change - can be expected to make potentially harmful activities increasingly common and widespread. As a consequence, conflicts have occurred between states over the interpretation and the implementation of the principlemost often in relation with unilateral infrastructure development on a shared river. Examples from around the world, including the Mekong, Syr Darya or the Nile river basins, have demonstrated the manifold negative impacts of such conflicts on regional relations, development, stability and peace.

These developments highlight a number of pertinent questions: The question of what constitutes harm and when does such harm reach the threshold of significance is often contested among riparian states in a basin-and the question then becomes a source of disagreement or conflict itself. Related questions on how to identify, measure and quantify harm and whom to hold liable for harm (and how) only add further complexity. Moreover, the principle of no significant harm needs to be interpreted and implemented in the light of the other key principle of international water law-the principle of equitable and reasonable utilization - with which it can be in a complementary as well as in a conflicting relationship, depending on the specific context in a given basin. Additionally, questions pertaining to procedural mechanisms that help address disagreements over the principle of no significant harm are also often insufficiently answered in many basins.

This Special Issue focuses on the principle of no significant harm in international water law and seeks to address some of the aforementioned questions. It aims at contributing to the academic debate around international water law principles as well as to the policy discourse on how to prevent significant harm and disagreements that emerge around the principle. It builds on the outcomes of the 2019 Water and Peace Seminar, held at IHE-Delft Institute for Water Education, in the Netherlands, during which leading academics and practitioners discussed the current state of the principle of no significant harm and its role in the prevention and mitigation of conflicts over shared water resources and the strengthening of peaceful and cooperative transboundary water management. The editors would like to acknowledge the resources made available by IHE Delft Institute for Water Education, the DUPC 2 Water Diplomacy project, financed by the Ministry of Foreign Affairs of the Netherlands, and the Earth Commission's work financed by the Global Challenges Foundation at the University of Amsterdam.

In the first article, Owen McIntyre assesses how the concept of no harm has evolved over time in international water law. He argues that countries may use their resources but must not cause substantial harm to others. In this context, they must show that they have exercised due diligence in the process of using and developing water resources and have tried to prevent or reduce possible harm to a level below the significance threshold. 
However, he also argues, that this is more difficult to assess and implement in practice: In assessing what due diligence is, one needs to look at not only legal developments in different fields, but also the changing context of water and environmental issues. At the same time, and depending on the political and economic development context, the no significant harm principle may be perceived as less important than the equitable and reasonable utilization principle by states, opening the route for additional disagreements.

Attila Tanzi addresses the specific relationship between the principle of no significant harm and the principle of equitable and reasonable utilization. He argues that the principle of no significant harm is closely linked to the principles of cooperation, and equitable and reasonable utilization, and that they can be clustered together under the notion of "community interest" which court judgements as well as state practice have promoted. He argues that the no significant harm principle should not be seen as conflicting or competing with the principle of equitable and reasonable utilization, but that the two are mutually supportive and should be regarded as such by both scholars and policy-makers and implemented accordingly.

The following article by Mara Tignio and Christian Bréthaut examines how the no significant harm principle has been applied in a number of court cases and how this has evolved over time. The authors trace a development from a focus on territorial integrity to increasingly addressing environmental impacts. The no significant harm principle is thus related, the authors argue, to protecting territorial integrity, equitable and reasonable utilization of water resources, but also to procedural principles such as the obligation to conduct Environmental Impact Assessments (EIAs), consult the local public or to protect minimum flows.

The fourth article, by Ruby Moynihan and Bjørn-Oliver Magsig, addresses questions around the role of international courts in a specific issue relating to the principle of no significant harm: the clarification of due diligence prevention and related compliance issues. Focusing on both international freshwater law and marine law and linking the two (thus highlighting the interdependence of both fields of law and a need for a source-tosea approach in the development of international law), they show that while compliance remains a challenge, specific international regimes have contributed to the normative development of the principle of no significant harm as a due diligence obligation. Further strengthening of cooperation between riparian states to shared watercourses as well as regional seas, including on procedural matters is, however, required in order to ensure full compliance.

As harm is often associated with large infrastructure projects that are often financed or developed by private companies or investors, Alistair Rieu-Clarke investigates what the principle of no significant harm implies for such projects. He focuses on the role of private investors that often develop and implement such projects and highlights that international law holds states accountable for the actions of private sector actors. He also demonstrates how rules for doing so remain insufficiently developed and are often not fully applied, presenting a challenge to the implementation of the principle of no significant harm. He therefore calls for clarity to be provided to both states and private companies to ensure that privately developed projects do not harm people, communities and other states but instead contribute to sustainable development.

The no significant harm principle is often accompanied by procedural mechanisms in order to ensure its effective implementation. Susanne Schmeier argues that the principle of prior notification can enable countries to notify other riparians of and discuss proposed projects. Such notification and consultation may avoid or mitigate potential disputes, thus making them not only procedural principles of international water law, but also instruments 
of water diplomacy. Although implementing prior notification is related to various challenges, basins which can rely on such mechanisms through basin treaties and basin organizations seem to cope better with disagreements over harm than those without.

Water resources projects often harm people and communities along the river, linking international water law principles with local people's and communities' concerns. This also links the principle of no significant harm with international human rights law and especially the human right to water. Otto Spijkers argues that the no significant harm principle and the human right to water are complementary. He reasons that while the no significant harm principle primarily concerns horizontal inter-state relations, it can be expanded to cover vertical (state-people) and diagonal (state-people of other state) relations. He illustrates this using the ongoing Silala waters dispute between Chile and Bolivia. In this case, a key issue is whether the Silala waters are transboundary and whether, even if they are not, states have certain responsibilities under the human right to water. He proposes further integration between these different legal fields.

Zooming into a comparative regional law perspective, Dinara Ziganshina and Barbara Janusz-Pawletta analyse the agreements of Central Asian countries in relation to the Aral Sea Basin (Afghanistan, Kazakhstan, Kyrgyzstan, Tajikistan and Uzbekistan), the Irtysh Basin (China, Kazakhstan and Russia) and the Chu-Talas Basin (Kazakhstan and Kyrgyzstan). They show that while these transboundary basin regimes refer to international water law principles, including the no significant harm principle, they treat what causes harm, how harm can be prevented, when harm crosses a threshold value and how such harm can be repaired differently. They call for further development of these concepts in these agreements and in Central Asia.

The last paper, by Joyeeta Gupta and Susanne Schmeier, examines the exponential nature of harm to the environment in general and to international watercourses in particular and how those are likely to increase in the future in the light of growing anthropogenic pressures. It compares this increasing harm with current efforts to further refine and more effectively implement the no significant harm principle as explained by the other authors. It calls for a quantum leap in the development of international water and environmental law and its implementation if the international community aims to be able to effectively respond to future challenges that arise from the intensified development of the world's water resources.

Together, these papers provide a comprehensive overview of the current state of the principle of no significant harm in international water law, its implementation in different locations and situations and its contribution to the sustainable and cooperative management of shared water resources. They also highlight the challenges that persist - with regard to the interpretation of the principle, its further elaboration and operationalization and its implementation. We hope that this provides a starting point for efforts at the global, basin and national level to further strengthen the principle of no significant harm in order to counter current and in particular future challenges that will arise for the world's water and ecological resources and systems and the people and countries depending on them.

Publisher's Note Springer Nature remains neutral with regard to jurisdictional claims in published maps and institutional affiliations. 